DANIEL J.B. MITCHELL

University of California, Los Angeles

\title{
Wage Pressures and Labor Shortages: The 1960s and 1980s
}

As THE U.S. unemployment rate fell during 1988 and early 1989 into the 5-5.5 percent range, observers worried about upward pressure on wage inflation. The concern grew naturally out of the experience of the 1970s, when wage inflation accelerated whenever the unemployment rate fell into the 6-7 percent range. But while such concern is understandable, it may be misplaced. Imagine an economic historian painting the following broad picture of the American labor market.

After two back-to-back recessions, and some adverse developments in the legal climate for unions, a period of calm descended on the labor market. Wage and price inflation receded against a background of relatively high unemployment. There was general concern that wage-setting practices and the climate of employment relations within firms was harmful to U.S. international competitiveness. Employers pushed for relaxations of workrules and wage freezes. The advance of union pay relative to nonunion was halted. Experiments were undertaken with flexible pay systems such as profit sharing in autos and gain sharing in other industries.

While there were some dramatic labor-management confrontations, strike activity fell notably. Cooperation seemed to be more in vogue than confrontation. Job insecurity, linked to both high unemployment and the spreading application of computers to the workplace, enabled employers to obtain concessions and cooperation in exchange for job guarantees and retraining programs for the displaced.

The author requested information on economic policymaking and interpretation in the 1960s from the following individuals whom he would like to thank for their assistance: Gardner Ackley, Barbara Bergmann, Lyle Gramley, Janet Norwood, the late Joseph Pechman, Robert Solow, James Tobin, and Lloyd Ulman. Katharine Abraham and Malcolm Cohen provided useful references. Maury Pearl and Ramanand Sood ably carried out necessary research assistance and conducted the telephone survey described in the paper. 
Experts warned that the better paying new jobs would go to those with professional and technical knowledge and projected a drying up of opportunities for obtaining high-wage blue-collar jobs. Fears were expressed that the American educational system was not turning out graduates with skills needed by the labor market, perhaps leading to a two-tier society with prospects of low wages and limited job opportunities for those on the bottom. At the same time there would be a dearth of employees with skills needed to meet the foreign challenge.

In time, however, demand expanded and the unemployment rate declined. Accompanying the decline were increased reports of labor shortages. Dissident movements arose in the union sector, challenging union officials who had previously negotiated contracts with low wage gains or who were seen as too cozy with management. Contracts negotiated by union officials were sometimes rejected by rank and file votes. Union officials, feeling the pressure, reminded management at companies such as Chrysler of previous concessions during hard times and demanded recoupment. Inflation of wages and prices accelerated.

The account, apparently of the labor market during the 1980s, actually describes the late 1950s and early 1960s. The back-to-back recessions, for example, occurred in 1957-58 and 1960-61. The unfavorable legal development for unions to which the story refers was the LandrumGriffin Act of 1959. Concerns about international competitiveness were easy to find in that era, as the world shifted from dollar shortage to dollar surplus. Employers did mount a bargaining campaign leading to wage freezes in some industries, notably steel. Flexible pay systems were negotiated at American Motors and Kaiser Steel. Workrule relaxations in exchange for job security were prominently featured in the West Coast longshore contracts. Labor Department projections emphasizing a drying up of blue-collar jobs and an expansion in technical and professional fields were widely publicized. ${ }^{1}$ Finally, as unemployment fell in the 1960 s, reports of labor shortages were heard with increasing frequency, and dissident movements in unions led to contract rejections and pressures on incumbent union officials. ${ }^{2}$ Concession bargaining waned. ${ }^{3}$

Despite notable differences-deliberately suppressed in the above story, but discussed later-between the 1960s and the 1980s, the similarities are sufficiently striking to make a strong case for seeking clues in the 1960 s, rather than the 1970 s, to the likely outcome of the recent

1. For example, Bienstock (1962).

2. Mitchell (1980, pp. 51-52); Sheahan (1967, pp. 57-60).

3. The opening hypothetical quotation referred to pressure on Chrysler in 1964 by auto workers to recoup past concessions. 
drop in unemployment below 5.5 percent. During the 1970 s, several developments made the economy unusually inflation-prone, pushing many estimates of the nonaccelerating inflation rate of unemployment (NAIRU) above 6 percent. The two most striking developments were the divergence of food and energy prices from the trend followed by other prices and the deterioration of productivity.

Through the 1960s, domestic farm prices were generally kept in line with other prices through government inventory policies. Stocks, however, were depleted during the late 1960 s so that by the 1970 s this policy no longer worked. ${ }^{4}$ Until the 1970 s, too, U.S. energy prices were partly insulated from external pressures by a quota system, and OPEC had not yet learned how to control world oil prices. In addition, world fixed exchange rates tended to keep international prices from gyrating in dollar terms and from rapidly changing the competitive position of American firms.

Thus, during 1959-69, the official consumer price index (CPI) and a component measure of underlying inflation that excluded food and energy prices both rose at the same 2.3 percent annual rate. During 1969-79, however, the figures for the two measures were 7.1 percent and 5.7 percent, respectively. Price volatility also increased in the $1970 \mathrm{~s}^{5}$ A divergence thus developed between measured price inflation and employer "ability to pay," that is, between the real wage and product wage.

The productivity slowdown after 1973, combined with these price developments, made obsolete the traditional notion of " 3 percent plus COLA" as an appropriate guide to wage setting. However, a failure to recognize these changes - and a spread of union COLA coverage due to higher inflation (or inflation uncertainty) and wage controls incentivescaused union wages to rise faster than nonunion until the early 1980s. And in aggregate, real wages (deflated by an appropriate "domestic" deflator) rose faster than productivity in the 1970s. Both tendencies

4. Hathaway (1974).

5. The official index is CPI-U after 1978 and CPI-W before. For underlying inflation, all items less food and energy have been used through 1967 and all items less food, energy, and shelter thereafter. (The latter measure excludes problems introduced by the inclusion of mortgage interest rates in the CPI during this period. However, it was not available until 1968.) The standard deviation of year-over-year CPI changes during 1959-69 was 1.5 percentage points. During 1969-79, it was 3.3 percentage points. 


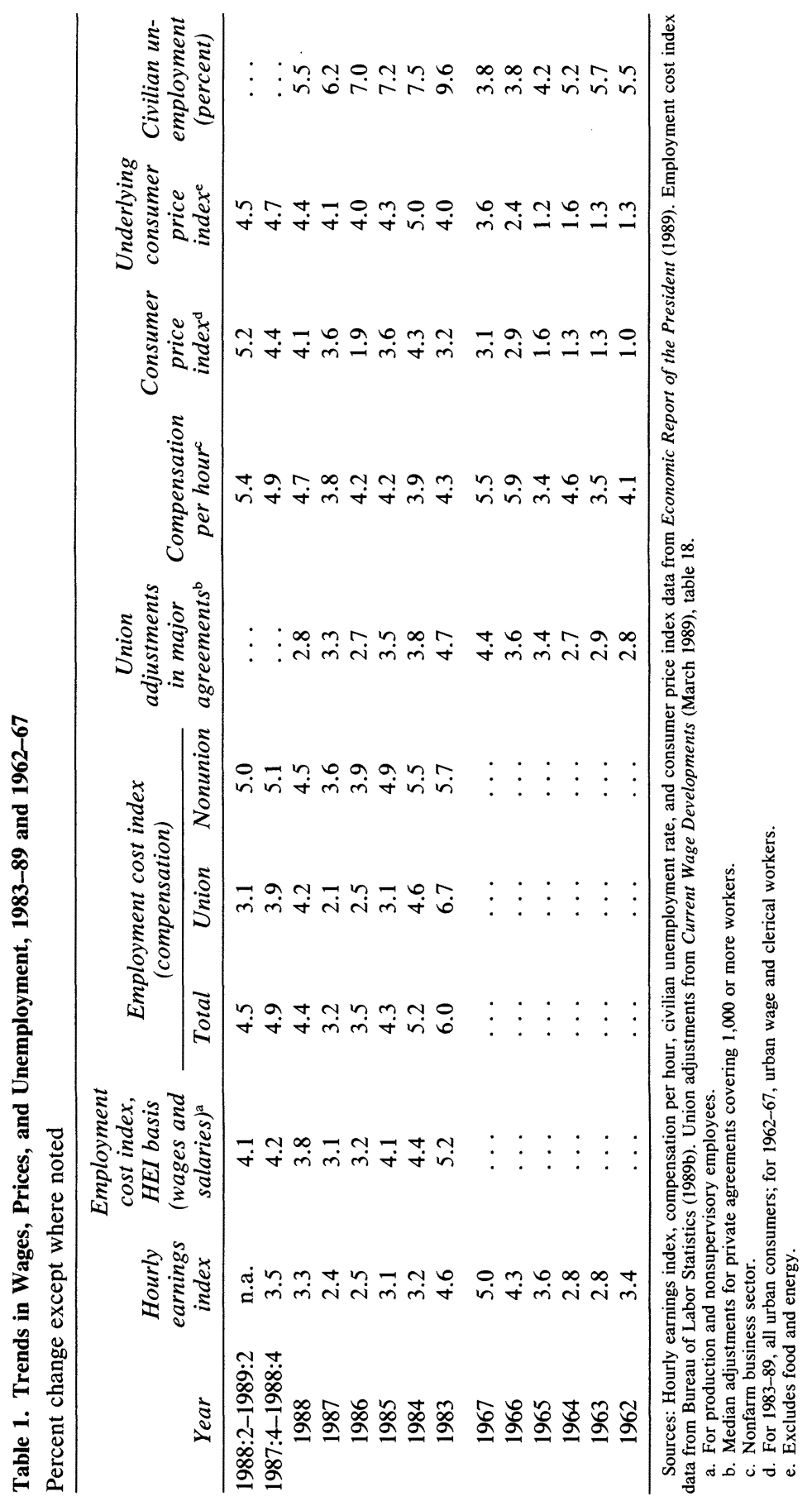


reversed in the $1980 \mathrm{~s}$, contributing to a climate of wage quiescence that resembled that of the early $1960 \mathrm{~s}^{6}$

Other forces that may have put greater pressure on wages in the $1970 \mathrm{~s}$ than in the 1980s include such intangibles as social turmoil, youth rebellion, and the entrance of the baby boom into employment.

All these differences between the 1970s and 1980s suggest strongly that the NAIRU—originally conceived as a relatively fixed concept-is actually subject to considerable variation across periods. An obvious short-term issue is whether unemployment below 5.5 percent (as achieved in late 1988 and 1989) is now compatible with price stability. And related to that is whether there are long-term institutional changes in labor markets that are reflected in a changing NAIRU.

\section{Initial Comparisons: 1960s and 1980s}

Table 1 summarizes wage and price trends and annual unemployment rates in 1983-89 and 1962-67. Of special interest is the contrast between 1988, during which unemployment averaged 5.5 percent (and was declining), and 1964, in which unemployment averaged 5.2 percent and again was declining. The various wage inflation indicators in 1988 all accelerated, although the acceleration halted during the first half of 1989 when the unemployment rate stopped falling. In 1964, only compensation per hour accelerated-apparently because of a combination of increased overtime hours and payments and supervisory salaries. ${ }^{7}$ Not until 1965 (and, on the price side, 1966) was inflation acceleration apparent.

6. For example, compensation per hour divided by the business deflator (the same deflator used to generate productivity and unit labor cost data) rose 0.9 percent annually during 1973-79, although output per hour rose only 0.6 percent. During 1979-88, the figures were 1.2 percent and 1.3 percent, respectively.

7. Unadjusted average hourly earnings in manufacturing rose 3.3 percent in 1964 compared with 2.5 percent for straight-time hourly earnings. The 0.8 percent difference is due to increased overtime, since otherwise the indexes would be identical. Unfortunately, data on overtime effects are not available for other sectors of the economy. Private wages and salaries per full-time equivalent worker from the national income accounts jumped 5.0 percent in 1964 (and then fell back to 3.4 percent in 1965), whereas unadjusted average hourly earnings rose 3.5 percent. If it is assumed that the 0.8 percent due to overtime in manufacturing applied to all sectors, then 0.7 percent remains of the 1.5 percent difference in the two indexes and may be due to differences in occupational coverage. The principal difference between the indexes in that regard is inclusion of nonproduction and supervisory workers in the national income measure. Hence, an upward move in white-collar salaries was probably at the root of the difference. 
The difference between developments in 1964 and 1988, it will be argued below, is explained by a combination of increased regional labor market diversity in the 1980s and institutional changes in labor and product markets since the 1960 s that reduce lags between demand impulses and wage reactions. These changes, it will be argued, have long-term macroeconomic significance that goes beyond trying to estimate the NAIRU of the late 1980s. Indeed, the fact that institutional changes can shift the NAIRU suggests that NAIRU estimates ought to be viewed as variables rather than immutable constants.

Several potential explanations for why, despite similar unemployment rates, the labor market of 1988 might be tighter than the market of 1964 turn out to be either unconvincing or difficult to assess. The first is that changes over the years in the demographic weights underlying the unemployment rate could obscure relative tightness. Second, differences in the perceived economic outlook may have favored wage advances in 1988. Third, labor markets may have become less efficient in the sense that higher vacancy rates existed in 1988 than in 1964 despite the roughly comparable official unemployment rates. Such inefficiency could be due to some institutional change (such as a shift in the unemployment insurance program) or a decline in labor quality of entry-age workers (forcing employers to search longer to find needed worker characteristics). Fourth, the baby bust phenomenon may have cut the supply of entry-age workers, thus creating a chronic tendency toward labor shortage.

\section{Changes in Demographic Weights}

Table 2 presents a detailed contrast between the official unemployment rate and alternative indexes of unemployment in 1964 and 1988. On the basis of pure demographics there is little difference between the two years. In 1964, the baby boom was just beginning to enter the labor market; in 1988 the baby boom was departing from the entry-age category. The proportion of men in the labor force was higher in 1964 than in 1988, but male unemployment rates rose relative to those of women in the 1980s, thus reducing the impact of the higher proportion of women.

If 1988 payroll weights (rather than purely demographic weights) are 
Table 2. Comparative Unemployment Data, 1964 and 1988

Percent except as noted

\begin{tabular}{|c|c|c|}
\hline Indicator & 1964 & 1988 \\
\hline Civilian unemployment rate & 5.2 & 5.5 \\
\hline Adult males, aged 25-54 & 3.2 & 4.4 \\
\hline \multicolumn{3}{|l|}{ Proportion of unemployed } \\
\hline Full-time workers & 83.9 & 80.0 \\
\hline Part-time workers & 15.7 & 20.0 \\
\hline Less than five weeks & 44.8 & 46.0 \\
\hline Female & 41.8 & 45.5 \\
\hline Aged 16-19 & 23.0 & 18.3 \\
\hline Aged 20-24 & 17.4 & 18.8 \\
\hline Mean duration of unemployment (weeks) & 13.3 & 13.5 \\
\hline $\begin{array}{l}\text { Normalized help-wanted advertising with Abraham adjustment } \\
\quad(\text { index, } 1964=100)^{\mathrm{a}}\end{array}$ & 100 & 94 \\
\hline Standard deviation of state unemployment rates divided by mean ${ }^{\mathrm{b}}$ & 0.24 & 0.34 \\
\hline $\begin{array}{l}\text { Standard deviation of demographic unemployment rates divided } \\
\text { by meanc }\end{array}$ & 0.68 & 0.68 \\
\hline \multicolumn{3}{|l|}{ Weighted unemployment rates } \\
\hline 1964 demographic weights ${ }^{c}$ & 5.2 & 5.5 \\
\hline 1988 demographic weights ${ }^{c}$ & 5.3 & 5.5 \\
\hline 1988 payroll weights ${ }^{d}$ & 4.4 & 4.9 \\
\hline Perry weights & 3.1 & 4.0 \\
\hline Civilian participation rate & 55.7 & 62.3 \\
\hline Nonagricultural full-time workers & 42.3 & 46.9 \\
\hline
\end{tabular}

Sources: 1988 payroll weights calculated from data from the Bureau of Labor Statistics. Perry weights provided by George L. Perry, the Brookings Institution. Normalized help-wanted advertising calculated from data in Survey of Current Business, 1965 and 1989, p. S-16 and S-14, respectively, and in Employment and Earnings (January 1989), table B.1. State unemployment rates found in Bureau of Labor Statistics, "State and Regional Unemployment in 1988," USDL report 89-73, February 17, 1989, and Manpower Report of the President (1965). Nonagricultural fulltime workers from BLS (1989c) and BLS (1965). All other data for 1988 from Employment and Earnings (January 1989). All other data for 1964 from BLS (1988).

a. Conference Board help-wanted advertising index divided by nonagricultural payroll employment and adjusted by factor suggested in Abraham (1987) projected to 1988.

b. Includes the District of Columbia as a state.

c. Demographic weights are based on the proportion of various groups in the labor force and apply to the following age groups by sex: 16-19, 20-24, 25-54, 55-64, 65 and up.

d. Payroll estimates are based on full-time and part-time median weekly earnings by demographic group.

used, prime-age men will count for more in the calculations because they earn more per hour than women do and also tend to work more hours. The Perry-weighted unemployment measure puts especially high weight on prime-age men and is in fact scaled to resemble their average unemployment rate. ${ }^{8}$ As can be seen from table 2, using any unemploy-

8. Perry (1972). 
ment index that puts heavy weight on men will indeed suggest a slacker labor market in 1988 than in 1964.

Women, however, are disproportionately among the new additions, as opposed to the incumbents, in the labor market. One contrast between 1964 and 1988 is the significantly higher labor market participation rate of women relative to men in the latter year. If new hires are what matters for wage setting, then unemployment indexes that put low weight on females may not adequately reflect demand pressures. As will be argued below, there is reason to believe that the labor market in the 1980s is more sensitive to outsiders than insiders, relative to the 1960s. Thus, the rationale that has traditionally been put forward for special emphasis on unemployment of adult men is being eroded by changing labor market conditions.

\section{Economic Outlook}

If the economic outlook was seen as more definitely expansionary in 1988 than in 1964, employers might have been more willing to raise wages that year than their counterparts were in 1964. However, if anything, the outlook during much of 1988 was gloomier and more uncertain than it was in 1964. The Kennedy assassination in late 1963 was undoubtedly a source of some uncertainty in early 1964. However, there was no reason to believe that President Johnson's economic policies would shift away from the expansionary emphasis laid out in the Kennedy administration, as economists of the period pointed out. Kennedy policies had been explicitly aimed at taking the unemployment rate down to 4 percent, well below the level prevailing in early $1964 .{ }^{9}$ And 1964 was also the year in which the famous tax cut, favored by administration economists on Keynesian grounds, was finally achieved.

Economic forecasting was generally "subjective" rather than econometric in the early 1960s. The business outlook panel of the National Industrial Conference Board, most of whose members assumed that a tax cut would be enacted, forecast an average unemployment rate for

9. "A Shock, Then Recovery," Business Week (November 30, 1963), pp. 92-93. The 4 percent civilian unemployment target would be equivalent to 3.8-3.9 percent under current definitions because of methodological changes in the collection of unemployment data made in 1967. These included slight wording changes in the Current Population Survey and exclusion of 14-15 year olds from the official definition of the labor force. 
1964 of 5.5 percent, falling to 5.3 percent by the fourth quarter. ${ }^{10}$ This view turned out to understate the actual rate of unemployment decline, although it did suggest a continuing drop in unemployment. Compendiums of forecasts were not published during this period, so it is difficult to know how typical the panel's view was. However, it might be noted that the administration's own forecast for 1964 correctly called for unemployment to decline to about 5 percent by the end of the year.

Whatever the sources of pessimism in 1964, their impact on forecaster expectations was clearly eclipsed by that of the October 1987 stock market crash. The consensus forecast for economic expansion was reduced by the crash, with some forecasters projecting outright recession. That the crash would not in fact provoke a recession was not clear for several months into 1988. Thus, if anything, the outlook during at least the first half of 1988 was more pessimistic than it was in 1964 . Although the economy expanded in the second half of 1988, forecasters, anticipating a monetary tightening by the Federal Reserve, became cautious again about 1989-90. It is hard to argue, therefore, that the economic outlook caused inflation to accelerate more quickly in 1988 than in 1964.

\section{Labor Market Inefficiency}

A third source of increased pressure on wages at a given unemployment rate in 1988 could be deteriorating labor market efficiency in matching jobs and workers since 1964. In particular, Katharine Abraham has suggested that the ratio of the vacancy rate to the unemployment rate has increased. ${ }^{11}$

Because official data on vacancy rates are not collected, direct observation of the Beveridge ratio is not possible. Help-wanted advertising, "normalized" by, that is, deflated by, employment, has been suggested as a proxy for the vacancy rate. Table 3 compares this proxy with a vacancy rate for the 1960 s calculated from data from state Employment Service agencies. (These data are not available for the 1980s.) Both series tell about the same story: 1964 saw some pickup in vacancies, but much larger jumps occurred in late 1965 and 1966, followed by a small decline during the "growth recession" of 1967.

10. National Industrial Conference Board (1963).

11. Abraham (1987). 
Table 3. Job Vacancies Pending at State Employment Services and Normalized Help-wanted Advertising, 1962-67

\begin{tabular}{lcccccc}
\hline \multicolumn{1}{c}{ Item } & 1962 & 1963 & 1964 & 1965 & 1966 & 1967 \\
\hline $\begin{array}{l}\text { Number of vacancies (thousands) } \\
\begin{array}{l}\text { Vacancies as percent of job } \\
\text { openings received }\end{array}\end{array}$ & 513 & 525 & 541 & 608 & 543 & 496 \\
$\begin{array}{l}\text { Normalized help-wanted advertising } \\
\text { (index, 1964 = 100) }\end{array}$ & 33 & 35 & 38 & 49 & 60 & 56 \\
\hline
\end{tabular}

Source: Pending vacancies from Employment Service Statistics, various issues. Help-wanted advertising from Bureau of Economic Analysis (1985) and from Employment and Earnings (January 1989), table B.1.

a. In December of year indicated.

b. Conference Board help-wanted advertising index divided by nonagricultural employment.

As Abraham has pointed out, the help-wanted index was affected after the mid-1960s by equal employment opportunity regulation (which encouraged advertising of job openings), changes in industrial organization of the newspaper industry, and other forces. Her corrections for these influences by the mid-1980s suggested a deflation factor for normalized help-wanted advertising of about 1.35 , increasing by about 0.8 percent a year. Thus, by 1988 , the correction factor would be about 1.39 .

As can be seen in table 2, normalized help-wanted advertising, adjusted by Abraham's suggested factor, was lower in 1988 than in 1964. It remained so during the first half of 1989 , despite the further lowering of unemployment. Thus, the inefficiency found by Abraham in the mid1980s appears to have mysteriously disappeared. It does not appear that the vacancy-to-unemployment ratio in 1988-89 was substantially higher than it was in 1964. Indeed, the reverse may be true.

Another source of labor market inefficiency could be institutional changes that reduce incentives for the unemployed to search for jobs. Unemployment insurance (UI) is sometimes blamed for discouraging rapid job search. Yet during the 1980s an exceptionally low percentage of the jobless participated in UI. The ratio of those receiving state UI benefits to total unemployment fell from 42 percent in 1964 to 35 percent in 1988. In addition, the ratio of average weekly UI benefits to average weekly earnings of production and nonsupervisory workers fell from 39 percent to 35 percent. ${ }^{12}$

12. Data on UI coverage and payment levels appear in the annual Economic Report of the President. 
Generally, it would be difficult to make a case that social welfare and labor standards legislation was less restrictive in 1964 than in 1988. For example, the ratio of the federal minimum wage to average hourly earnings was higher in 1964 than in 1988. If there was increased inefficiency in the labor market in 1988 , it did not stem directly from public policies.

Labor market efficiency in matching workers and jobs might be reduced by changes in the quality of job applicants, if such a quality change reduced employers' ability to appraise prospective workers. There is evidence, based on declines in SAT scores and other measures of school achievement, that quality of new entrants to the work force did decline after the mid-1960s, although there was some reversal of this trend in the 1980s. The popular press has often carried reports of declining discipline at the high school level. However, not all measures point to a decline in labor force quality. The absenteeism rate for illness, for example, was lower in 1988 than in the mid-1960s. And data on jobhunting methods used by the unemployed do not suggest a decline in the vigor of their searching process. ${ }^{13}$

Even if there has been a quality decline in available labor, that decline by itself would not necessarily reduce labor market efficiency; it could simply result in reduced wages for the lower-quality job seekers. And, indeed, the ratio of youth to adult wages for full-time workers has steadily declined, as table 4 shows. Note, however, that the decline could be due to demand-side factors such as shifts in the industrial and occupational composition of job openings.

Despite the ambiguity of the available information, the suggestion of a quality decline that has made it more difficult for employers to differentiate applicants cannot be ruled out. There have been reports that employers are having difficulty finding individuals with adequate

13. The proportion of nonagricultural employees not working because of claimed illness was 1.4 percent in 1964 compared with 1.2 percent in 1988 , according to Current Population Survey data. This rate rose in the late 1960s and peaked at 1.6 percent during the early 1970s, perhaps a symptom of social unrest in the workplace. It has steadily declined thereafter despite a rising ratio of those who are absent due to illness who report they are receiving sick pay. (The rate does not seem to show any short-term cyclical effect.) Data on job search were not available from the Current Population Survey before 1970. Since that date, however, the number of job-searching methods has shown an upward trend from 1.56 methods used (out of six choices in the survey) to 1.61 in 1988. This upward trend occurs within demographic groups as well as for the total. 
Table 4. Youth-Adult Ratio, Usual Weekly Earnings of Full-time Wage and Salary Earners, 1970-88, Selected Years ${ }^{\mathrm{a}}$

\begin{tabular}{|c|c|c|c|c|}
\hline & \multirow[b]{2}{*}{ Year } & \multicolumn{2}{|c|}{ Earnings ratio } & \multirow{2}{*}{$\begin{array}{l}\text { Youths as percentage } \\
\text { of civilian labor force }\end{array}$} \\
\hline & & Male & Female & \\
\hline & 1970 & 70 & 92 & 21.6 \\
\hline & 1975 & 64 & 80 & 24.1 \\
\hline & 1980 & 61 & 79 & 23.7 \\
\hline & 1983 & 55 & 74 & 21.7 \\
\hline & 1984 & 55 & 72 & 21.1 \\
\hline & 1985 & 54 & 71 & 20.5 \\
\hline & 1986 & 53 & 71 & 19.8 \\
\hline & 1987 & 54 & 70 & 19.2 \\
\hline & 1988 & 54 & 70 & 18.5 \\
\hline
\end{tabular}

Sources: Earnings ratios for 1970 and 1975 from Bureau of Labor Statistics (1982), table B.25. Ratios for 1988 from Employment and Earnings (January 1989). All other earnings ratios from Bureau of Labor Statistics (1988), table A.9. Youths as percentage of civilian labor force from Employment and Earnings (January 1989), table 3.

a. Youths are individuals aged 16-24. Adults are those 25 years and older. Ratios computed from medians.

basic skills. ${ }^{14}$ An informal telephone survey by the author (described more fully below) found that 42 percent of management respondents had complaints about basic skill deficiencies of new job applicants. Perhaps grade inflation and a tendency to pass along students who do not meet minimum standards have reduced the information content of educational credentials.

\section{The Baby Bust}

The argument that a labor shortage is linked to the baby bust is not supported by table 2 . The proportion of workers aged 16-24 was about the same in 1964 and 1988. If there had been a special shortage of young workers, it might be expected that youth wages would have started rising relative to adult wages by 1988 , with its 5.5 percent unemployment rate. No such tendency is evident in table 4 . Lack of a minimum wage increase has undoubtedly influenced the youth-to-adult wage ratio, although it

14. The National Association of Manufacturers conducted a mail survey of small businesses. Only 15 percent responded that they were not having problems with their employees' "'education and training." Thirty-seven percent complained of math deficiencies, 30 percent complained of reading and writing problems, 25 percent had difficulties in training their employees, and 50 percent said they had problems with employee ability to resolve problems independently. These data were kindly provided to me by Christian $\mathrm{N}$. Braunlich of the NAM. 
might be noted that the data of table 4 are based on full-time workers, whose wages are normally higher than those of part-timers. Perhaps shifts in the industrial and occupational composition of job openings were so adverse to youth that rising wages for them within industries and occupations were obscured. But it is more likely that the effects of the baby bust, whatever they may turn out to be, will be felt in the 1990s as the ratio of young people to the overall work force declines further.

\section{Regional Labor Market Diversity}

Several studies have noted that increased diversity in the labor market could produce a mix of tight and loose market conditions, thus making the wage-setting process more inflation-prone at any average unemployment rate. ${ }^{15}$ Unemployment, for example, could vary widely across industries, across demographic groups, or across regions. As the average unemployment rate fell, those groupings with the lowest unemployment rates would bump into labor shortage situations and begin raising wages.

The data used to calculate the alternative unemployment rates in table 2 reveal no increased variation in unemployment by demographic group. And earlier studies do not suggest that differences in unemployment by industry have widened. ${ }^{16}$ However, regional variation in unemployment does seem to have increased notably between 1964 and 1988, as the table indicates. In addition, partly because of the already-mentioned increased volatility in relative pricing that began in the 1970 s, it is possible to have separate boom-bust cycles in agriculture, oil, and manufacturing.

This drift away from a uniform macroeconomy was particularly notable in the northeastern states, where employers have complained of labor shortages for several years. One Massachusetts personnel manager reported in late 1986 that "we don't go through applications to pick the most qualified people any more. Now we hire anybody and say 'Be all that you can be.' "'17 As might be expected, such pressures show up as an upward wage drift in the northeastern states relative to the rest of the country. ${ }^{18}$ Table 5 shows a rise of wages in the Northeast relative to

15. Abraham (1987); Baily (1984).

16. Abraham (1987).

17. Richter (1986).

18. Disparities in unemployment across regions are mirrored in other data as well. For example, the dispersion of per capita personal income showed a long-term narrowing trend until the 1980 s when it markedly widened. 
Table 5. Regional Wage Trends, 1983-88

Percent change

\begin{tabular}{lcccccccc}
\hline Region & 1983 & 1984 & 1985 & 1986 & 1987 & 1988 & $\begin{array}{c}\text { Change in wage } \\
\text { relative to } \\
\text { Midwest, } \\
1982-88\end{array}$ \\
\hline Northeast & 5.4 & 4.6 & 5.0 & 4.7 & 4.6 & 4.7 & 6.6 \\
South & 5.1 & 4.9 & 4.2 & 3.4 & 2.6 & 3.6 & 1.5 \\
Midwest & 4.9 & 4.5 & 3.9 & 2.9 & 3.1 & 3.1 & $\ldots$ \\
West & 5.6 & 3.6 & 4.6 & 2.7 & 2.4 & 3.3 & 0 \\
\hline
\end{tabular}

Source: Current Wage Developments (March 1989), table 15. Data refer to employment cost index for wages and salaries, based on annual averages of quarterly figures.

those of the Midwest and West of more than 6 percent since the 1980s recovery began.

However, one must be cautious about exclusive reliance on regional disparities in unemployment as an explanation of seemingly higher NAIRUs. For example, Abraham's data suggest that disparities in state unemployment rates during the late 1970s, when unemployment was relatively high, were quite low relative to those during later years. Hiring survey data from Manpower, Inc., suggest that in the late 1970s, the regional and industrial disparities in net job openings were higher than they have been in the late 1980s. Thus, in the late 1970s, diversified employer demand bumped up against constraints in relatively uniform labor markets. During the late 1980s, the reverse was true: in widely diversified labor markets, employers have been uniformly demanding more labor and bumping against barriers in those markets that were already tight. ${ }^{19}$

In short, of all the explanations offered so far for why the 1980s might be more inflation-prone than the 1960 s, regional diversity seems most

19. Mary B. Stewart of Manpower, Inc., kindly provided me with historical data. On a quarterly basis, the Manpower, Inc., survey asks employers-broken down into 11 industrial sectors and 4 regions-whether they plan to increase or decrease their work forces in the next quarter. The reports use the difference between the percentage planning increases and the percentage planning decreases as an index of net hiring intentions. Using 10 of the 11 sectors broken down by region and 1 sector (mining) on a national basis, I calculated the standard deviation of net intentions for the third quarter of 1978, 1979, 1988, and 1989 (surveyed in the second quarter). The standard deviations dropped from 14.79 and 11.97 in 1978 and 1979, respectively, to 9.12 and 8.04 in 1988 and 1989. Standard deviations divided by the mean for these years were $0.58,0.59,0.40$, and 0.35 . 
convincing. Evidence of a softening of the previously tight northeastern labor market in the second half of 1989 relative to other regions therefore suggests a possible further lowering of the NAIRU as regional markets become more nearly alike. As noted earlier, there is no immutable law setting the NAIRU above the level achieved in the 1960s.

\section{Institutional Changes in the Response of Wages}

While regional diversity may be one way in which the 1980s differ from the 1960s, other institutional changes have occurred that may have more important and lasting effects on labor market behavior. In particular, the erosion of the big firm, big union, Galbraithian economy of the mid-1960s has quickened the reaction of wages to a tightening labor market, with possibly far-reaching implications for the inflationary behavior of the economy.

\section{Economic Debate in the 1960s}

The Keynesian economists in the Kennedy-Johnson administrations arrived in Washington committed to reducing unemployment and stimulating economic growth. However, they were confronted by structuralists arguing that unemployment could not be much reduced because of worsening mismatches in labor demand and supply. The structuralist argument ran across the political spectrum. Liberals, including some in the Department of Labor, used it to justify federal expenditures on "manpower" programs and aid to education. Conservatives used it to argue against Keynesian demand-stimulus remedies-an argument heard within policy circles of the Federal Reserve Board and expressed in the unpublished minutes of the Federal Open Market Committee. ${ }^{20}$

In its first Economic Report of the President, the Kennedy adminis-

20. I obtained microfilms containing minutes of the Federal Reserve Open Market Committee. These minutes are more detailed than those officially published by the Federal Reserve and indicate the opinions of specific members. For an example of an expression of the structuralist view at the FOMC, see the minutes of January 1, 1964, microfilm M591, reel 23, National Archives, statement of member Hayes: "Certainly there is nojustification in keeping it [monetary expansion] up in order to cope with an unemployment problem which is in large part structural. ...", 
tration set a 4 percent "interim" target for unemployment and argued that structural unemployment lay below this target. The possibility of achieving the target by mid-1963 was discussed. Use of the adjective "interim" stemmed from a belief by some of the new economists that a rate even below 4 percent was in fact sustainable. Yet the Council of Economic Advisers was clearly concerned about possible inflation as the unemployment target was approached. The concern was based not on fears of a generalized labor shortage but rather on a bargaining theory of wage setting and an oligopolistic view of price setting.

Specifically, as the economy expanded, it was considered possible that unions might demand large wage increases or that oligopolist industries might push up prices before the target was achieved, thus thwarting the unemployment goal. To combat these potential developments, the Report proposed wage-price guideposts, tying suggested wage settlements to trend growth in productivity and price setting to cost markups. Later, the wage target was explicitly set at 3.2 percent. When the economy achieved 5 percent unemployment by the end of 1964 without substantial inflation, the CEA argued that there were still ample supplies of labor available to permit a noninflationary lowering of unemployment.

The contrary structuralist view had several elements. Generally, the argument was that demand in the labor market had shifted toward educated, skilled labor, but supply had not followed suit. In short supply were scientists, engineers, and technicians; in excess supply were the unskilled who might once have been picked up in blue-collar manufacturing jobs. This analysis was based in part on data on shifts in the occupational and industrial mix in the 1950s. The view was reinforced by numerous projections by Labor Department officials and from Labor Department documents aimed at high school guidance counselors. It was linked to the fear that computerization would lead to massive displacement of industrial workers. ${ }^{21}$ CEA economists, however, attributed the sluggishness of job opportunities in unskilled and semi-skilled blue-collar jobs in the late 1950s to a soft economy; jobs at the lower end of the skill range would expand if aggregate demand were boosted. Keynesians outside the administration generally shared the CEA view.

21. The Labor Department did not officially support the structuralist position. But its documents emphasized that job expansion would be faster than average in professional, technical, and skilled fields. See U.S. Bureau of Labor Statistics (1963); Diebold (1962). 
There were other influences contributing to the power of the structuralist approach, apart from past labor force trends. In a vague way, the structuralist view was combined with the notion that the United States should somehow produce more scientific personnel in order to keep up with the Russians. It was the converse of the current notion that the United States should turn out fewer lawyers to emulate the Japanese.

The CEA, anxious to combat the idea that structural unemployment had invisibly crept up in the 1950 s, undertook studies to refute the view that it had. In retrospect, it appears that at least some of the fall in unemployment after 1964 can be attributed to such structuralist factors as the increased military draft and enrollments in manpower programs. However, removing the absolute (as opposed to incremental) influence of the draft and manpower programs from 1964 in fact suggests that the labor market was even tighter that year than in 1988 than the comparison of overall unemployment rates reveals. That is, in structuralist terms, the quiescence of wages in 1964 becomes all the more a mystery.

Although policymakers at the Federal Reserve were more likely to accept the structuralist view of unemployment than that of the more optimistic Keynesians at the CEA, both the CEA and the Federal Reserve shared one view: the importance of following union wage settlements as guides to future inflation. The CEA's guideposts inherently were union-focused since union wage decisions were more visible and publicized than nonunion counterparts. At the Federal Reserve, members of the Open Market Committee took note of major union settlements, such as the auto settlement of 1964 , as possible pattern setters for other wages.

Thus, when the auto settlements provided no first-year basic wage increase, it was seen as a sign that the inflation threshold had not been crossed. The auto contracts seemed to continue the pattern of zero basic wage adjustments seen in the much-watched steel contracts in 1962 and 1963 , although observers noted that the nonwage elements appeared to exceed significantly the 3.2 percent guideposts. By late 1964, however, signs of discontent among union workers could be seen. Observers of the industrial relations scene (correctly) predicted the electoral ouster of the president of the steelworkers' union, who was identified with zero wage settlements and moves toward labor-management cooperation. ${ }^{22}$

22. Fogel and Meyers (1964). 
And, indeed, the 1965 steel settlement ended the zero pattern. Strike activity increased, and strikes were increasingly centered on general wage adjustments.

\section{The Changing Importance of the Union Sector}

It is not difficult to understand why union settlements were so closely watched in the early to mid-1960s. As table 6 indicates, union workers represented a much larger fraction of the overall work force then than they do now. Sluggish economic conditions, especially in the union sector, produced minor membership losses in the early 1960s, but nothing like the large drops seen in the 1980s. Although precise data are not available, about 6 out of 10 union workers were under contracts covering 1,000 or more workers. ${ }^{23}$ Econometric evidence developed in the early 1960s was viewed as confirming the pattern-setting influence of key contracts that had been widely asserted by industrial relations experts. ${ }^{24}$

Perhaps more significant than the number of union workers is the proportion of labor compensation that was union-negotiated. Union pay is higher than nonunion, and union workers work longer weekly hours. Thus, the importance of union pay is understated by employment counts. As the informal table below indicates, a 1 percent increase in union wages in the early $1960 \mathrm{~s}$ was sufficient to raise aggregate compensation 0.4 percent, apart from any pattern-setting influence on nonunion workers. In contrast, the figure for the late 1980 s was about 0.2 percent. ${ }^{25}$

$\begin{array}{cccccc}1958- & 1963- & 1968- & 1978- & 1983- & 1988 \\ 1959 & 1964 & 1969 & 1979 & 1984 & \end{array}$

Union sector compensation as proportion of total private compensation

23. The BLS did not begin estimating the proportion under such contracts until 1967 and the estimate jumped markedly in 1968, partly because of employment growth but also probably because of more complete data. In 1968, the number of workers estimated to be under major private contracts was 10.4 million, over 60 percent of estimated private union membership in that year. See Ward and Davis (1968, p. 20); Troy and Sheflin (1985, p. A2).

24. Eckstein and Wilson (1962).

25. Technical details underlying the calculations used to obtain the estimates in the informal table can be found in Jacoby and Mitchell (1988). The 1988 estimate in the table 
Table 6. Trends in Private Sector Union Representation, 1959-88, Selected Years ${ }^{\mathrm{a}}$

\begin{tabular}{cccc}
\hline Year & $\begin{array}{c}\text { Union } \\
\text { representation } \\
\text { density } \\
\text { (percent) }\end{array}$ & $\begin{array}{c}\text { Union } \\
\text { representation } \\
\text { workers } \\
\text { (millions) }\end{array}$ & $\begin{array}{c}\text { Major union } \\
\text { representation } \\
\text { as percentage } \\
\text { of all union } \\
\text { representation }\end{array}$ \\
\hline 1959 & 32 & 14.6 & $\ldots$ \\
1964 & 31 & 15.1 & $\ldots$ \\
1969 & 29 & 16.9 & $\ldots$ \\
1980 & 22 & 15.5 & 60 \\
1988 & 14 & 11.8 & 52 \\
\hline
\end{tabular}

Source: Data for 1959-69 from Troy and Sheflin (1985, pp. A1-A2). Data for 1980-88 from Bureau of Labor Statistics (1981, p. 28) and Mitchell (1989b, p. 495).

a. 1980 figures for total representation refer to May. Major union representation (agreements covering 1,000 or more workers) is as of October for 1980 and September for 1988.

\section{Big Firms and the Administered Sector}

The discrepancy between the 1960 s and 1980 s is especially marked with regard to trends in firm size and trends in employing units. As table 7 shows, the Fortune 500, the archetypal Galbraithian firms, grew in employment at a faster clip than the overall economy during the 1960s. But in the 1980s, employment at the Fortune 500 shrank absolutely even as total employment elsewhere expanded.

Similar trends are evident from County Business Patterns data; as table 8 shows, larger employing units grew more rapidly than others in the 1960s, but contracted in the 1980s. Moreover, this tendency was not simply a reflection of the relative growth of manufacturing and services. As the table shows, the same trends are observed within manufacturing. Employment trends in the union sector (table 6) show that workers under major contracts (those covering 1,000 or more employees) have declined relative to total union employment, mirroring the move to smaller

\footnotetext{
is an extrapolation based on unionization in that year of the data described in the JacobyMitchell paper. However, the estimation technique used to adjust the data for fringe benefits is probably upward biased and the figures may be off by 1-2 percentage points. According to unpublished data from the BLS, for the private employment cost index in December 1988, the union weight was 24.6 percent. However, the ECI methodology overstates union importance during periods of union decline. The 1988 weights are based on employment counts as of 1980 , not 1988, adjusted for changes in the union and nonunion pay trends. Thus, the weights do not take account of the big decline in unionization after 1980 .
} 
Table 7. Employment Trends, Fortune 500 and Private Nonagricultural Sector, 1960-88, Selected Years

Millions

\begin{tabular}{ccc}
\hline Year & $\begin{array}{c}\text { Fortune 500 } \\
\text { (millions) }\end{array}$ & $\begin{array}{c}\text { Private } \\
\text { nonagricultural } \\
\text { (millions) }\end{array}$ \\
\hline 1960 & 9.2 & 45.8 \\
1964 & 10.5 & 48.7 \\
1969 & 14.8 & 58.2 \\
Annual percent change, 1960-69 & 5.5 & 2.7 \\
1979 & 14.8 & 73.9 \\
1988 & 12.7 & 88.7 \\
Annual percent change, 1979-88 & -1.7 & 2.0 \\
\hline
\end{tabular}

Source: "The Fortune 500," Fortune, annual April issue, various years. Employment and Earnings (March 1989), table B.1.

business units. ${ }^{26}$ Although the existence of the trend is more important for current purposes than the cause, it is worth noting that some observers attribute the move in the 1980 s to smaller units as technologically driven and likely to continue. ${ }^{27}$

While industrial mix does not explain the shrinkage of employing units, it does reinforce it. The informal table below shows the percentage of employees in what might be loosely called the "administered" sector: mining, manufacturing, transportation, and public utilities.

$\begin{array}{lllll}1959 & 1964 \quad 1969 \quad 1979 \quad 1988\end{array}$

Administrative sector as percent

$\begin{array}{llllll}\text { of total private nonagricultural employment } & 47 & 45 & 43 & 37 & 29\end{array}$

This sector accounted for 45 percent of employment in the mid-1960s; by the late 1980s it accounted for less than 30 percent and less than a

26. Comparable data are not available for the 1960s. The BLS did conduct a survey of wage developments in manufacturing during that period. Based on data from that survey, it appears that the proportion of workers in manufacturing under major agreements fell from 62 percent to 57 percent during 1959-69. It is quite possible, however, that growth of smaller units was exaggerated during this period as the BLS identified more small units for the survey pool as it continued to undertake the survey. (Larger units would have been easier to identify and thus the survey would have been more complete from the beginning in the major sector.) Data for manufacturing for $1980-88$ on a basis comparable to table 6 indicate a drop in the proportion of union workers covered by major agreements from 56 percent to 43 percent.

27. Piore and Sabel (1984). 
Table 8. Employment Trends by Size of Establishment, 1962-69 and 1979-86 Annual percent change

\begin{tabular}{lrrrrr}
\hline \multirow{1}{*}{ Years } & \multicolumn{5}{c}{ Number of employees } \\
\cline { 2 - 6 } & $1-99$ & $100-499$ & 500 or more & $500-999$ & 1,000 or more \\
\hline 1962-69 & 3.2 & 4.3 & 4.4 & $\ldots$ & $\ldots$ \\
All & 1.4 & 3.4 & 3.7 & $\ldots$ & $\ldots$ \\
$\quad$ Manufacturing & & & & & \\
1979-86 & 2.1 & 2.1 & $\ldots$ & 0.0 & -0.3 \\
All & -0.1 & -1.2 & $\ldots$ & -2.6 & -3.1 \\
Manufacturing &
\end{tabular}

Source: County Business Patterns, U.S. Summary, 1964, 1969, and 1986, table 1B. 1962-69 data refer to "reporting units." $1979-86$ data refer to establishments.

fourth if transportation and utilities are dropped from the sector because of deregulation.

Changes in the industry mix of employment can affect average pay rates by pushing employment toward or away from higher-wage employers. Comparison of the BLS data on average hourly earnings and its hourly earnings index (which standardizes for industry composition) suggests that during 1979-88 the industry mix effect reduced wages 1.8 percent for production and nonsupervisory workers. In contrast, the industry mix effect slightly raised average pay during the 1960 s for this group. ${ }^{28}$

The BLS now publishes an index as a component of the employment cost index for production and nonsupervisory workers that corrects for both industry and occupational mix. A comparison of the occupationindustry corrected index with the industry-corrected hourly earnings index permits an estimate of the occupation effect. The comparison suggests that changes in occupational composition reduced pay 5.1 percent during 1979-88. Thus, during the 1980s employment was being shifted toward lower-wage employers and lower-wage jobs, that is, jobs least likely to be cushioned from labor market forces by union contracts and bureaucratic personnel practices.

In short, the big firm, big union, administered sector of employment, no matter how defined, was considerably larger and more important in

28. The hourly earnings index (which was discontinued after 1988) was standardized for industry mix and overtime in manufacturing. It did not correct for overtime in other industries, causing some unknown error to enter into the comparisons in the text. 
the setting of prices and wages in the 1960s than it was by the late 1980s. There was scope for a transitory reduction of wage premiums in the 1960 s economy as demand rose. Big unions were adversely affected by the downward shift in wage norms in the early 1960s; long-term contracts (by then common) further slowed the union response as unemployment fell. Reinforcing this structural difference was the existence of the wageprice guideposts program, which could put downward pressure on key, that is, big and visible, players. At least on the wage side, observers of the period found evidence of such an inflation-retarding effect. ${ }^{29}$

\section{Inflation Expectations: Then and Now}

The inflation experience of the work force in the early 1960s was quite different from that of the current work force. In 1962, for example, the median age of the work force was more than 40 , that is, old enough for more than half the work force to remember the deflation of the Great Depression. In the mid-1980s, in contrast, the median age was about 35; most of the work force had no experience with sustained price deflation.

Good data on inflation expectations for the general population are not available. However, data from the University of Michigan's Survey Research Center suggest that during the early 1960s, about 30 percent of the household respondents surveyed expected prices would either stay the same or fall in the year ahead. This proportion had dropped to about a fourth by early 1964 . There had not actually been a single year of CPI decline or constancy since 1955 . But the notion that prices might be stable or declining provided a stabilizing anti-inflation anchor. Indeed, the fact that the Survey Research Center would ask questions about inflation not in terms of what rate to expect but whether prices would rise, fall, or stay the same is itself revealing.

The Livingston survey provides an indication of the inflation expectations of economic forecasters, which may not be accurate reflections of what wage setters were thinking. These data suggest a backwardlooking, moving-average process of expectations. In 1964, forecasters expected annual rates of inflation of 1.2 percent; in 1988, they anticipated

29. Perry (1967); Sheahan (1967, chap. 7). 
4.9 percent. ${ }^{30} \mathrm{~A}$ similar picture emerges from examination of long-term bond yields.

It can be argued that inflation expectations matter a lot for wages set under long-term contracts but not so much for wages set in something closer to a spot market. In that case, low expectations of inflation may have had more of a dampening effect on wage setting in the mid-1960s than similar expectations would have on current wage determination. Indeed, there is evidence from recent surveys of wage-change expectations that these expectations play little independent role in contemporary wage setting.

A number of management consulting firms and other organizations now conduct surveys of white-collar (and therefore largely nonunion) wage setting. Since 1983, Charles Peck of the Conference Board has collected these surveys in a feature appearing in the Board's annual Human Resource Outlook publication. ${ }^{31}$ Most of the surveys break down the white-collar work force into executives, salary-exempt, and salarynonexempt employees. The reports indicate average predicted percentage salary adjustments by worker classification for the next year (PRED) recounted by respondents for their own organizations. Also reported are the average actual salary adjustments in the current year $(A C T){ }^{32}$ By following the reports, it is possible to determine how accurately the previously projected increases determined subsequent actual outcomes for each worker classification in each survey. A total of 92 observations reported during 1984-89 were available. ${ }^{33}$

30. Unpublished Livingston survey data were kindly provided by John M. Tynan of the Federal Reserve Bank of Philadelphia.

31. The reports were originally titled Labor Outlook. I wish to thank Mr. Peck and Elizabeth R. Arreglado of the Conference Board for supplying me with data.

32. The reports are typically published on the basis of increased salary budgets per employee. Because of peculiarities (and confusion) in the human resource field about the proper accounting of merit increases for current employees, these reports tend to exaggerate actual average pay increases by 1-2 percentage points. Essentially, the projections include the gross cost of merit increases without an offset for the salary savings that occur as senior workers leave and lower-paid new hires replace them. For details, see Mitchell (1989a, pp. 93-97).

33. Included in the Peck reports were surveys by the American Compensation Association, the Conference Board, Executive Compensation Service (Wyatt), Handy, Hansen, Hay, Hewitt, Mercer, Sibson, and TPF\&C. Not all were present in each year. At the time this paper was written, only data from the Conference Board were available for 1989. 
Regression analysis based on these data suggests that compensation managers make their predictions about next year's pay adjustment largely on the basis of past pay change in their firm and in the surrounding economy together with anticipated changes in labor market conditions. Specifically:

$$
\begin{aligned}
& P R E D_{\text {for } 0}= 0.64+0.76 A C T_{-1}+0.26 E C I_{-1}-0.07 U_{-1} \\
&(0.16) \quad(0.04) \quad(0.03) \\
& \bar{R}^{2}=0.94,
\end{aligned}
$$

where $P R E D$ refers to the prediction made for year 0 in year $-1, E C I$ is the percent change in the employment cost index for private white-collar workers, $U$ is the June unemployment rate, and standard errors are shown below the coefficients. ${ }^{34}$ The predictions, however, are not statistically significant as forecasters of actual salary outcomes. That is:

$$
\begin{aligned}
& A C T_{0}=1.21+0.29 P R E D_{\text {for } 0}+0.56 A C T_{-1} \\
& \begin{array}{lll}
(0.27) & (0.18) & (0.14)
\end{array} \\
& +0.28 E C I_{-1}-0.18 U_{0}-0.08 U_{-1} \\
& \begin{array}{lll}
(0.06) & (0.07) \quad(0.04)
\end{array} \\
& \bar{R}^{2}=0.83,
\end{aligned}
$$

where all coefficients are significant except that of PRED. In short, it appears that although compensation managers made predictions about wage inflation in the 1980 s, their anticipations did not seem to matter. What did matter was an update on the information the managers had about labor market conditions.

In summary, in the 1960s-a period in which a larger fraction of wages was set under long-term contracts, was influenced by such contracts, or was set in a contract-like process-prevailing inflation expectations probably helped to dampen wage changes initially as the labor market

34. The June date for $U$ was used because it approximates the period in which the surveys are taken. $E C I$ refers to total compensation on a fourth-quarter-to-fourth-quarter basis. It should be noted that $A C T$ is not a final measure of actual pay but rather the respondents' statement of what the planned increase for the current year is. Experiments to determine whether in making predictions respondents projected future unemployment rates produced anomalous results. Specifically, the actual value of $U$ in the equation for $P R E D$, that is, the year-ahead actual unemployment rate that respondents might be rationally predicting, entered with a significant positive sign. Peculiarities in the relatively short data period may be responsible for this result. 
tightened. During the 1980s, wage setters had higher expectations of inflation than they did in the 1960s, but these expectations probably had less importance, since most wages were being set outside a long-term contract framework.

\section{Changes in the Employer-Employee Relationship}

The argument being made here is not that the labor market has become an auction-style spot market but rather that it has shifted along a spectrum in that direction. Thus, relative to the 1960 s there are less likely to be lags in response to demand pressures. Employers will raise wages if they have to for retention and recruitment. During the first half of 1989, for example, Federal Reserve policies aimed at slowing the economy did succeed in halting the previous acceleration of wage inflation.

There is still lethargy in wage setting, as the coefficient on $A C T_{-1}$ as a determinant of $A C T_{0}$ suggests. But institutional changes suggest that the lethargy is likely to be less of a factor in the future than it was in the past. These changes involve not only the shrinkage of the union and large firm sectors, but also shifts in the employer-employee relationship.

\section{Employment Tenure}

It is ironic that just as economists began to detect and rationalize longterm employment tenures, actual tenure began to decline. Table 9 summarizes available time series data on median job tenure. It might have been expected that as young baby boomers entered the labor market in the 1960s and 1970s, median tenure would decline. However, such demographically determined tenure changes should have reversed in the 1980 s.

Unfortunately, BLS broke the series in 1983 by changing the question from job tenure to employer tenure. ${ }^{35}$ But the fact that tenure fell according to the new series from 1983 to 1987 suggests that the secular trend seen in the old series is continuing. Table 10 shows that tenure fell in all age classes except 35-44 (where the boomers are aging).

35. Job tenure will be shorter than employer tenure since a worker can change jobs and remain with the same employer. 
Table 9. Job Tenure Trends, 1963-87, Selected Years

Median years of tenure

\begin{tabular}{llcc}
\hline Series and year & All & Males & Females \\
\hline New series & & & \\
1987 & 4.2 & 5.0 & 3.6 \\
1983 & 4.4 & 5.1 & 3.7 \\
Old series & & & \\
1981 & 3.2 & 4.0 & 2.5 \\
1978 & 3.6 & 4.5 & 2.6 \\
1973 & 3.9 & 4.6 & 2.8 \\
1968 & 3.8 & 4.8 & 2.4 \\
1966 & 4.2 & 5.2 & 2.8 \\
1963 & 4.6 & 5.7 & 3.0 \\
\hline
\end{tabular}

Sources: Hamel (1963, 1967); Sekscenski (1979); Horvath (1982); Sehgal (1984).

Some of the fall in tenure may be due to the decline in the union sector of the work force, where longer-than-average tenures are found. Some may be due to the decline in employment at large firms and to industrial restructuring. The financial approach to enterprise control, that is, the view of the firm as a portfolio of detachable and mergeable assets, and the related increased pace of mergers, acquisitions, and divestitures, tends to undermine stable employment policies. It is difficult for employees to have a relationship with an employer whose identity keeps changing.

\section{Contingent Workers}

There have been increasing reports of expanded use of contingent workers by U.S. firms in the 1980s. The definition of "contingent" is imprecise; commentators seem to mean employees who do not have "regular"' jobs with their employers but are instead hired on a temporary basis with fewer entitlements, especially to benefit plans. However, the concept is sometimes expanded to include employees hired by smaller subcontractors (who handle peak work for other firms) and self-employed workers. Employers are seen as having fewer obligations to such workers and as hiring them essentially in a spot market.

Richard Belous, for example, put the contingent work force between 25.0 percent and 28.5 percent of the civilian work force in 1980 and 
Table 10. Job Tenure Trends, 1983-87, by Age Group

\begin{tabular}{lrrrrr}
\hline & \multicolumn{2}{c}{$\begin{array}{c}\text { Median years } \\
\text { of tenure }\end{array}$} & & \multicolumn{2}{c}{$\begin{array}{c}\text { Percent with tenure } \\
\text { of 20 years or more }\end{array}$} \\
\cline { 2 - 3 } Age group & 1983 & 1987 & & 1983 & 1987 \\
\hline All & 4.4 & 4.2 & 9.9 & 9.3 \\
$16-24$ years & 1.5 & 1.2 & & $\ldots .1$ & $\ldots .0$ \\
$25-34$ years & 3.5 & 3.4 & & 0.1 & 0.0 \\
$35-44$ years & 5.8 & 6.1 & & 5.0 & 5.2 \\
$45-54$ years & 10.2 & 9.6 & & 23.4 & 22.7 \\
$55-64$ years & 13.6 & 12.7 & 34.8 & 33.7 \\
65 and over & 13.2 & 12.4 & 38.1 & 38.1 \\
\hline
\end{tabular}

Source: Sehgal (1984, p. 19); Daily Labor Report, October 23, 1987, p. B4. Data as of January.

a. Less than 0.05 .

between 29.9 percent and 36.6 percent in $1988 .{ }^{36}$ His upper-limit estimate includes workers supplied by temporary help agencies, part-timers, workers in the business service sector, and the self-employed. There are obvious problems with such a definition, especially with regard to the inclusion of business services and the self-employed. His lower-limit estimate excludes business services and agency temporaries, but still includes the self-employed.

An alternative definition counting only agency temporaries and parttimers would put the estimates at 17 percent in 1980 and 21 percent in 1988. The difficulty is that existing labor market data do not pick up the degree of employer commitment to the employee. Some part-timers, for example, may be longstanding employees while others are hired on a contingent basis. Many employers appear to have internal mechanisms for hiring temporaries; not all temps are hired through agencies. And temporary employees often work full time.

Because of the growing interest in the contingent worker phenomenon, several surveys have been taken of its use. A Bureau of National Affairs report, for example, found that 81 percent of responding companies reported some use of part-timers, 59 percent hired their own temporaries, 84 percent hired temporaries through outside agencies, and 57 percent used subcontracting. ${ }^{37}$ Katharine Abraham's nonrandom survey of BNA respondents in 1985, however, found a major gap between usage and the

36. Belous (1989, p. 16).

37. Bureau of National Affairs (1988b). 
proportion of work time actually performed by contingents (defined as agency temps, short-term hires, and on-call workers). ${ }^{38}$ Such workers accounted for only 1.5 percent of work time, although the distribution was skewed, with some firms reporting substantially heavier usage. Not surprisingly, these heavy users were firms facing significant demand variability. Thus, it might be expected that if the proportion of firms facing demand uncertainty increases over time, use of contingent workers will also increase.

It is difficult to find useful time series on the contingent phenomenon. A 1987 BLS survey of selected distressed industries found that their use of subcontracting has been increasing. Larger firms seemed to make more use of flexible practices than small, suggesting that such firms were compensating for rigid practices for incumbent workers by flexibility on the margin. ${ }^{39}$ Employment through temporary agencies has expanded rapidly since the 1982 recession trough but still accounts for less than 2 percent of the work force. Initially, the employer motivation in using such services was probably to avoid making job commitments after having gone through a period of retrenchment. By the late 1980s, however, the agencies were being used as de facto recruitment tools in situations where clerical or other types of employees were in short supply.

Despite the lack of good data, it is likely that the fraction of the work force hired on a short-term, temporary, or contingent basis has increased in the 1980s. The magnitude of the contingent phenomenon, however, may not be accurately measured in recent reports. Part-time work is the only continuous proxy for contingency available with a long time series. In 1964, the proportion of nonagricultural part-time employees was 14 percent; by 1988 it had reached 18 percent, an increase but not a revolution.

\section{Contingent Pay}

It may well be that employment contingency is itself a symptom for a reduced sense of employer obligation to stabilize incomes for the work force as a whole, including regular workers. In theory, the rise of

38. Abraham (1988).

39. Murphey (1989); BLS (1987). 
contingent workers could be a way of protecting core incumbents. However, there is evidence, again loose evidence, that the incidence of contingent pay systems for incumbents, such as profit sharing, has been increasing. ${ }^{40}$ The BLS estimates that 21 percent of full-time employees in medium-to-large firms had profit sharing in 1988, although, unfortunately, a long-term time series is not available for this estimate. ${ }^{41}$

Within the union sector during the 1980s, the use of lump-sum bonuses became widespread as an alternative to wage increases. In late 1988, 51 percent of workers under major private, nonconstruction union agreements had lump sums in their contracts, compared with 48 percent in 1987. Such bonuses hardly existed before the early $1980 \mathrm{~s} .{ }^{42}$ The bonuses most commonly are paid as flat dollar amounts and are commonly concentrated in the first year of the contract. The average flat dollar amount negotiated in 1988 was $\$ 848$, according to one survey, perhaps 3-4 percent of a typical private union worker's pay. Percentage-denominated bonuses also fell into that range. ${ }^{43}$ Lump sums are now often used in contracts where no first-year wage increase is specified, but are also common in contracts in which the wage is raised.

Typically, lump sums provide some direct saving to the employer because certain fringe benefits are geared to the wage (exclusive of the bonus). In addition, workers hired after the effective date of the bonus do not receive it. Thus, a 3 percent bonus costs less in the year in which it is effective than a 3 percent wage increase. However, there may be more to the growth of the bonuses than simple cost savings.

There is evidence that the norms of the labor market make it easier to reduce elements of compensation labeled bonuses than those labeled

40. Mitchell, Lewin, and Lawler (1990). It is unclear whether the proportion of firms offering profit sharing has notably changed. What matters, however, is the proportion of employees covered. At one time, profit sharing was viewed as mainly a benefit plan for managers and-where the benefit was more widely spread-mainly for smaller firms. The surveys of the U.S. Chamber of Commerce do not show dramatic changes in the proportion of firms with profit sharing, but these surveys do not report the proportion of employees covered.

41. BLS (1989a, p. 138).

42. For that reason, data on lump sums prior to the mid-1980s are nonexistent. The text figures come from the January 1988 and 1989 issues of the Monthly Labor Review, pp. 16 and 13 , respectively. Construction workers are omitted since they typically have only casual relationships with employers, and lump sums are therefore not practical. (No lump sums were reported for construction in either year.)

43. Bureau of National Affairs (1989). 
wages. ${ }^{44}$ Thus, it is possible that over several rounds of bargaining, the bonus element might prove to be more variable than the wage, that is, to be an ersatz profit-sharing plan like that some observers find in the Japanese system of bonus payments. ${ }^{45}$ Recent evidence suggests that demand uncertainty (proxied by a shock prior to negotiations) increases the probability that a lump-sum union contract will be negotiated. ${ }^{46}$

It is important to note that spread over all workers (union and nonunion), lump sums appear to be a relatively minor element of pay at present. They are probably concentrated in the union sector, which is now a small part of the private economy. (Data on nonunion lump sums are not available or are likely to be confounded with other kinds of bonus plans.) BLS estimates of the proportion of pay going to "nonproduction bonuses" came to only 0.8 percent of compensation as of early 1989.47

Phenomena such as contingent workers and contingent pay suggest that employers may be pulling away from long-term commitments to job and income stability. The observable parts of these phenomena may be the tip of a much larger iceberg. If so, data on the proportion of contingent workers in the labor force or the proportion of compensation in contingent pay understate changes that have occurred in wage setting. Thus, the kind of wage stickiness in response to demand associated with longterm relationships is likely to have been, and to be, reduced.

\section{Responsiveness of Competitive Wages}

Is it in fact the case that more competitively determined wages will be more responsive to demand fluctuations? There is evidence that union wages in the mid-1960s responded more slowly than nonunion as demand and price inflation accelerated. ${ }^{48}$ Table 1 indicates a widening of the gap between the all-sector hourly earnings index and union wage adjustments after 1965. Beyond that, within manufacturing, if smallness of size is taken as a proxy for competitiveness, it appears that in the mid-1960s wages moved up faster in smaller establishments.

44. Kahneman, Knetsch, and Thaler (1986).

45. Freeman and Weitzman (1987).

46. Erickson and Ichino (1989).

47. U.S. Bureau of Labor Statistics, press release USDL: 89-295, June 15, 1989. The author confirmed with BLS that lump sums are annualized in the survey to avoid understatement of their yearly magnitude.

48. Mitchell (1980, p. 40). 
Table 11. Manufacturing Wage Change by Size of Employing Unit, 1963-67

Percent

\begin{tabular}{lcccccc}
\hline & \multicolumn{6}{c}{ Employees in reporting unit } \\
\cline { 2 - 7 } Item & $1-99$ & $100-249$ & $250-499$ & $500-999$ & $1,000-2,499$ & 2,500 or more \\
\hline $\begin{array}{l}\text { Annual change in payroll } \\
\text { per employee }\end{array}$ & 4.8 & 3.8 & 3.5 & 3.2 & 2.8 & 3.1 \\
$\begin{array}{l}\text { Annual change in } \\
\text { employment }\end{array}$ & 0.4 & 3.0 & 3.9 & 4.0 & 4.3 & 5.8 \\
\hline
\end{tabular}

Source: Bureau of the Census (1967), table 1.

Table 11 provides data from the Census of Manufactures on payroll per employee during 1963-67. (Unfortunately, comparable data were not available for other sectors from business censuses, nor for the 1980s.) It appears from the table that larger establishments, with their preexisting wage premiums, were able to add workers as demand expanded. Smaller establishments had to boost wages competitively in response. If in the late 1980s competitive pressures are more widely spread among businesses, the pattern of wage sensitivity observed in the 1960s for smaller units may well be more uniform across size classes.

\section{Labor Shortages}

Certainly, evidence that employers are having difficulty recruiting new employees would be a harbinger of wage inflation to come. What does an economy with recruitment problems look like? Again, the experience of the 1960s is enlightening. Examination of articles in the popular and trade press and in official sources of that era reveals the following pattern.

\section{Official Reports}

Official sources, such as reports from the Employment Service, described shortages of personnel in specific occupations throughout the early 1960s, especially health care workers, scientists, and engineers. Certain skilled blue-collar workers were also said to be in short supply. Similar views appear in the annual Manpower Report of the President, which generally devoted far more attention to labor surpluses than to shortages until 1965. 
The 1965 Report (largely written, it may be presumed, in late 1964 and early 1965) included extensive discussion on health, science, and other professional personnel for which labor market pressures were apparently being felt. Thus, the period surrounding the writing of the report emerges as one of transition, balanced between labor shortages in selected fields and labor surpluses elsewhere. By 1966, with unemployment below 4 percent, the tone of the Report changed; brave assertions were made that government manpower programs would be available to deal with the growing tautness of the labor market. ${ }^{49}$

Studies of labor market pressures, issued regularly by the Labor Department by order of the president beginning in 1966, acknowledged "imbalances" but argued that real shortages would not exist until unemployment fell to the extremely low levels seen during the Korean War. ${ }^{50}$ The reasons for this insistence on minimizing labor market pressures were undoubtedly partly political. But the academic division of unemployment into demand, structural, and frictional categories may also have played a role. Only when a purely frictional element was left (a level identified with wartime conditions) would a shortage be acknowledged, regardless of resulting wage pressures.

\section{The Popular and Trade Press}

As might be expected, the popular and trade press was less restrained in its reaction to changing labor market conditions. ${ }^{51}$ In mid-1964, the press still was writing about automation and displacement. But by the latter half of the year, occasional shortage stories began to appear. "A Good Man Is Hard to Find," declared one headline. By mid-1965, reports appeared on the virtues of relaxing hiring standards and considering previously unwanted job applicants.

However, the real flood of labor shortage articles began in late 1965, articles whose flavor can easily be sensed from their titles: "Help Wanted-Almost Everywhere," "Too Much Employment?," "'Skilled

49. Manpower Report of the President (1966, pp. 31-34).

50. The Korean War comparison is made in news release USDL-7299 (July 3, 1966). Insistence that there were "imbalances," but not an "overall labor shortage," appears in release USDL-7151 (April 8, 1966). Janet Norwood, BLS Commissioner, kindly provided me with samples of these reports.

51. Many articles from trade journals and the popular press are mentioned briefly in this section. Full bibliographical citations are available from the author. 
Labor Pinch Gets Tighter," "Labor Shortages Become Acute," "Help Wanted-And Very Badly." Other articles suggested solutions for employers such as obtaining foreign labor, stepping up internal training programs, or enlarging job duties of existing workers.

Articles on labor shortages in the past few years have not pointed to anything like the general demand pressures seen beginning in late 1965 . Since the mid-1980s, some articles, based mainly on demographic projections of the baby bust, have warned of an impending shortage. Others, reminiscent of the early 1960s, complain of a growing structural mismatch problem involving basic skill and education deficiencies. Still others argue, however, that potential employees among current nonparticipants in the labor force or in high-unemployment areas can move into available jobs. Employers are being advised to find ways to recruit current nonparticipants. Surprisingly, given the interest in the effects of recently enacted immigration controls, these controls have not generally been referenced in the shortage articles.

Recent shortage articles that cite actual employer recruitment problems, as opposed to demographic projections, have been focused on problems in particular industries, regions, or occupations. They have tended to spotlight health care, some parts of retailing, and clerical employees in particular areas. For several years, there have been complaints that low-wage jobs in services, fast food, and small businesses generally are hard to fill.

Some of this problem at the bottom of the wage scale may be due to the lack of an increase in the federal minimum wage after 1981. Employers who were used to queues at the legal wage floor have had to bid for employees as the floor fell in relative terms. However, there have also been reports of worker shortages in high-wage settings. McDonnell Douglas was reported recently to have imported certain skilled workers from Britain and to be making heavy use of overtime to overcome a labor shortage. Boeing in Everett, Washington, has rented excess workers from a Lockheed facility in Marietta, Georgia.

The impression left by the labor shortage articles is that $1988-89$ is roughly equivalent to late 1964 and early 1965 . That is, a 5-5.5 percent unemployment rate in the late 1980 s seems equivalent to a $4.5-5$ percent unemployment rate in the $1960 \mathrm{~s}$, at least in terms of journalistic response. In both cases, spot shortages were reported in selected sectors and regions, and localized problems were seen as becoming more numerous. 
But there was not wholesale excess demand for labor. The labor market, as described in both cases in the press, seemed very close to, if not already at, the point where increasing wage inflation could pose a problem.

\section{Confirming Surveys}

Several organizations have begun to undertake management surveys of labor shortages. Table 12 reports such a survey conducted by the American Society for Personnel Administration in late 1988. As in all such surveys, earlier data are not available for comparison. And the results therefore tend to be ambiguous. A tight labor market was clearly indicated for the Northeast. Across the country, many respondents reported having some difficulties finding labor. But many did not. ${ }^{52}$

The ASPA survey broke down the country into six regions for each of the seven occupations shown in the table. When asked about future shortages relative to present, in 40 of the 42 region-occupation pairs the proportion expecting future "great or very great" difficulties in recruiting was higher than the proportion reporting present difficulties. When asked about strategies for recruitment and retention problems, the most common response was wage increases (58 percent).

More recent data from an informal survey undertaken by the author during June-August 1989 are summarized in table 13. The survey, of members of the American Compensation Association, was taken by telephone rather than by mail to avoid potential selective response biases..$^{53}$ In loose terms, however, the telephone survey paints a picture

52. The survey was taken, by mail, of 4,470 ASPA members. The response rate was 16 percent (707 usable forms). ASPA membership is undoubtedly biased toward larger firms with formal personnel policies. (The survey did not ask for size of firm.) A previously cited survey of small manufacturing firms by the National Association of Manufacturers in April-May 1989 suggested similar recruiting results for skilled workers, but less of a problem for clericals and unskilled workers. Questions were asked about mid-level and senior executives, but many firms responded that they did not have such titles. Over 2,200 firms responded, a 25 percent response rate.

53. Mr. John Ferrence of the ACA kindly provided an up-to-date address listing. Two research assistants called members of the ACA (other than non-U.S. residents, management consultants, and individuals employed in public administration). They were instructed to attempt to reach the individual but if problems were encountered in making contact, for example, the individual was on vacation, simply to call the next person on the address list. Of 304 successful contacts, only 4 refused to respond. In contrast, there may be a tendency 
Table 12. Results of ASPA Labor Shortages Mail Survey, September-October 1988 Percent

\begin{tabular}{|c|c|c|c|c|}
\hline \multirow[b]{3}{*}{ Occupation } & \multicolumn{4}{|c|}{$\begin{array}{l}\text { Employer characterization of difficulty } \\
\text { in recruiting }\end{array}$} \\
\hline & \multirow{2}{*}{$\begin{array}{c}\text { Not at } \\
\text { all-very } \\
\text { small }\end{array}$} & \multirow[b]{2}{*}{ Moderate } & \multicolumn{2}{|c|}{ Great-very great } \\
\hline & & & $\begin{array}{l}\text { United } \\
\text { States }\end{array}$ & Northeast \\
\hline $\begin{array}{l}\text { Executive and administrative } \\
\text { managerial }\end{array}$ & 57 & 32 & 11 & 18 \\
\hline Sales & 56 & 28 & 16 & 12 \\
\hline Professional & 46 & 29 & 25 & 26 \\
\hline Office clerical & 50 & 23 & 27 & 50 \\
\hline Unskilled & 53 & 19 & 28 & 51 \\
\hline Technical and technical support & 34 & 35 & 31 & 35 \\
\hline Skilled and crafts & 37 & 27 & 36 & 62 \\
\hline
\end{tabular}

Source: American Society for Personnel Administration (1989, pp. 8-15). See text for details.

similar to that of ASPA. That is, there is a spread of responses in all regions, although the gap between the Northeast and the rest of the country was not statistically significant. ${ }^{54}$ But as expected, respondents willing to characterize the labor market as very tight represent a smaller proportion of the telephone survey than in the potentially biased ASPA mail survey.

What do employers in the late 1980 s who do report labor shortages do in response? In general terms, they do what employers in the $1960 \mathrm{~s}$ did when they experienced what Arthur Okun termed a "high-pressure" economy ${ }^{55}$ According to the results of the telephone survey, they look harder for workers ( 86 percent), upgrade existing workers ( 73 percent),

for mail surveys to be answered selectively by individuals who were having recruitment problems or who otherwise had strong views on the topic and thus had an interest in the survey.

54. Answers from manufacturing respondents were not significantly different from those in nonmanufacturing industries with regard to perceptions of labor shortages. Similarly, answers from respondents in the Northeast were not significantly different from those in other regions. (A chi-squared test was used to test for significant differences.) It might be noted that respondents sometimes referred to conditions outside their geographical area, if their firms had multiple locations. Thus, the table, which is based on the location of the respondent, may blur actual differences. However, the softening of the Northeast labor market during the period of the survey (relative to that of the ASPA survey) may also have played a role in the lack of a statistically significant difference.

55. Okun (1973). 
Table 13. Results of Labor Shortage Telephone Survey, June-August 1989

Percent

\begin{tabular}{|c|c|c|c|c|c|c|}
\hline \multirow[b]{2}{*}{ Item } & \multicolumn{3}{|c|}{$\begin{array}{c}\text { Employer characterization } \\
\text { of problem }\end{array}$} & \multicolumn{3}{|c|}{ Duration of problem } \\
\hline & None & Limited & General & $\begin{array}{l}\text { Past few } \\
\text { months }\end{array}$ & Past year & Longer \\
\hline All regions & 44 & 50 & 6 & 17 & 33 & 50 \\
\hline Northeast & 40 & 47 & 12 & 9 & 41 & 50 \\
\hline All other & 45 & 50 & 5 & 19 & 31 & 50 \\
\hline \multicolumn{7}{|l|}{ Excluding problems } \\
\hline of more than one year & 61 & 34 & 5 & 35 & 65 & 0 \\
\hline Manufacturing & 50 & 45 & 5 & 18 & 32 & 50 \\
\hline Nonmanufacturing & 40 & 52 & 7 & 17 & 33 & 50 \\
\hline
\end{tabular}

Source: Telephone survey by author. See text for details. Figures may not sum to 100 because of rounding.

use more overtime ( 40 percent), or pay bonuses to new hires ( 20 percent) or to incumbent employees who refer a new hire (40 percent). Pay increases (71 percent) are an important response, but not the only response undertaken.

The telephone survey makes it possible to remove respondents who report that the recruitment problems they are experiencing are longstanding. Since there are almost always recruiting difficulties in some occupations (and always chronic complainers), respondents who report longstanding problems may not be typical of those who report more recent demand pressure. The table shows that about half the respondents who do not have chronic problems reported no recruitment problems at all. This result suggests that if surveys such as ASPA's excluded individuals who always report recruitment problems, the labor market would appear less tight than their raw figures suggest.

\section{The Decline of Union Concessions}

In the mid-1980s, I reported on the tendency of union concession agreements to spread from industry to industry, despite the economic recovery then under way.$^{56}$ By various measures, concession bargaining was diminishing by the late 1980s, as it had in the mid-1960s. That is, the union sector was being affected by the same economic forces as the nonunion.

56. Mitchell (1985). 
Table 14. Trends in Union Wage Concessions, 1961-69 and 1981-89

\begin{tabular}{ccc}
\hline Yercent of & $\begin{array}{c}\text { Pettlements } \text { with } \\
\text { no first-year } \\
\text { wage increase }\end{array}$ & $\begin{array}{c}\text { Severity } \\
\text { index }^{\mathrm{a}}\end{array}$ \\
\hline 1961 & 7 & $\ldots$ \\
1962 & 10 & $\ldots$ \\
1963 & 10 & $\ldots$ \\
1964 & 8 & $\ldots$ \\
1965 & 5 & $\ldots$ \\
1966 & 2 & $\ldots$ \\
1967 & 1 & $\ldots$ \\
1968 & $1^{\mathrm{b}}$ & $\ldots$ \\
1969 & 0 & $\ldots$ \\
1981 & 2 & 0.10 \\
1982 & 12 & 0.19 \\
1983 & 29 & -0.20 \\
1984 & 27 & -0.35 \\
1985 & 25 & 0.12 \\
1986 & 37 & 0.27 \\
1987 & 34 & 0.26 \\
1988 & 27 & 0.47 \\
$1989^{\circ}$ & 20 & 0.71 \\
\hline
\end{tabular}

Source: Daily Labor Report, various issues; Mitchell (1989b).

a. See text for definition.

b. $0-1$; precise proportion not available.

c. First six months.

Table 14 provides two measures of concession bargaining. The first series shown follows the same definition used in my previous study: the proportion of settlements involving a basic wage freeze or cut in the first contract year. This series peaked in 1986 and had fallen to about a fifth of new contracts by the first half of 1989 . However, freezes and cuts have become a progressively upward-biased index of concessions because of the complexity of supplementary provisions that are being negotiated. Workers who receive no basic wage increase may still receive first-year income increases through COLA clauses, lump sums, or profitsharing payments, for example.

As a supplementary measure, therefore, the table shows an index of concession severity applying to all contracts with no positive base wage adjustments in the first year. The severity index rates contracts from -3 (most severe) to +3 (least severe) by assigning points to various contract 
provisions. A wage decrease received a -2 , a two-tier plan -1 , an active (nonfrozen) COLA clause 1, a profit-sharing plan 1, and lumpsum bonus 1 . As the table shows, concession severity-as measured by this admittedly arbitrary index-peaked in 1984 . The main factor reducing severity has been the growing tendency to include lump sums in contracts with no base wage increase. This tendency was especially evident during the first half of 1989 in the paper and lumber settlements that accounted for 33 percent of the concessions of that period.

Apart from what can be seen directly in wage-change and wage concession indexes, the union sector is experiencing symptoms of increased militancy among members and local officials. There have been increased reports of rejections of, or resistance to, contracts negotiated by higher union officials. These tendencies, illustrated by the developments listed in the appendix, are reminiscent of similar movements in the latter half of the 1960s. A key difference, however, is that because of membership losses, unions are not well positioned today to become independent sources of wage pressure. Most of the decline in unionization in the 1980s was not due to changing employment mix across industries. Over 80 percent of the drop in private sector unionization during 1980-88 (table 6) was due to declining unionization within sectors. ${ }^{57}$ Thus, the level of nonunion competition faced by the typical union negotiator is substantially higher than it was in the 1960s. Not surprisingly in this environment, surveyed unionized employers indicate that they are increasingly confident of obtaining their bargaining goals in future negotiations..$^{58}$

\section{Conclusions}

In the 1960s, wage inflation accelerated when the unemployment rate fell toward the bottom of the 4-5 percent range. By the late 1970s, the comparable range was 6-7 percent. And by the late 1980 s, it had fallen back to an intermediate 5-6 percent.

The comparatively low levels to which unemployment could fall in the 1960s without speeding up inflation were associated with a big firm,

57. Mitchell (1989b).

58. Bureau of National Affairs, Inc. (1988a). 
big union economy whose wage-setting processes reacted sluggishly to demand pressure. The wage-price guideposts program and the greater regional uniformity of unemployment rates during the 1960s also retarded wage inflation as the average unemployment rate fell. The 1960s economy was more truly macroeconomic than that of the $1980 \mathrm{~s}$.

It took time for wage setters, especially in the union sector, to adapt to the diversification of the labor market that began in the 1970s. Wage setters had to realize that CPI-measured inflation was not necessarily a good index of employer ability (or willingness) to pay. The product wage and the real wage might move divergently. Deterioration of productivity growth also caused confusion among wage setters, by undermining the basis of the " 3 percent plus COLA" notion. While the learning process was under way, the range of unemployment in which inflation would accelerate rose. Ultimately, the environment became unfavorable to sluggish and slow-to-adapt wage-setting arrangements.

During the last half of 1988 and the first half of 1989 , as the unemployment rate fell into the 5-5.5 percent range, signs of wage pressure appeared, especially the rash of reports of labor shortages. The atmosphere became reminiscent of 1965 , a year that can be seen in retrospect as a transition to sustained inflationary problems. But there is a difference between the mid-1960s and the late 1980s. Changes in labor market institutions have pushed wage setting in a more competitive direction. While the labor market is far from a textbook auction, in the current period what you get is what you see. Long lags are not likely to occur.

In some respects, these circumstances make inflation fighting easier. If 5-5.5 percent unemployment is now the rate that triggers accelerating inflation, policymakers will observe that fact fairly quickly. Federal Reserve policy did move toward restraint, especially in the first half of 1989. The unemployment rate stopped falling, and wage-change acceleration was checked. It will be evident soon enough if maintaining the rate in the 5-5.5 percent range is sufficient to contain inflationary pressure. 
APPENDIX

Recent Developments

in the Union Sector

FOLLOWING ARE brief descriptions of selected union actions during 198889.

Airlines. Eastern Airlines workers strike to protest demands for wage and other concessions beginning March 1989. Unions become involved in various buyout proposals before bankruptcy court.

Coal. United Mine Workers strike against Pittston Co., which broke away from employer bargaining group and did not become party to group contract. Wildcat strikes and picketing at other companies develop in spring 1989. Violence erupts at some sites.

Electrical equipment. Local union presidents recommend rejection of GE contract negotiated in June 1988 by national officials of the Electronic Workers. Contract is ultimately ratified by membership after campaign by national union. Workers at former RCA TV manufacturing plants reject tentative agreement reached by national union with new owners (Thomson Consumer Electronics).

Motor vehicles. 1988 Chrysler contract providing no first-year basic wage increase ratified by close margin despite national union endorsement. Union officials express surprise at narrow vote. Skilled trades group within Chrysler pushes for reopening of new contract but fails to convince national union. Dissident movement within Auto Workers develops opposing "team concept" and related labor-management cooperative devices, but fails to make significant political gains within union.

Retail food. In Richmond, Va., a three-year 1987 Safeway contract providing for wage cuts is replaced in early 1989 (well before expiration) by a new agreement providing wage increases. The employer explains that the new agreement would "reaffirm to . . employees our commitment to staying in the area. ..."

Rubber. Goodyear workers reject tentative 1988 agreement between union and company that froze wages but continued COLA. Impasse 
eventually settled by renegotiated contract that provided an "advance" COLA payment. Other companies follow Goodyear pattern.

Steel. Workers reject tentative settlement at National Steel. A subsequently renegotiated contract that contained what the union described as "slight improvements" was later ratified.

Telephones. Tentative 1989 agreement at GTE California rejected by union members. Renegotiated contract calls for wage increases in place of lump sums. Subsequent negotiation with Pacific Bell also leads to rejection of tentative contract.

Trucking. Members reject National Master Freight Agreement in May 1988 by 64 percent vote. Union permits contract to go into effect despite vote because of internal rule that contract rejections require two-thirds vote. Subsequent Carhaulers pact, rejected by 72 percent vote and ultimately renegotiated, eliminates provision allowing lower labor costs for new routes. 